\title{
IMPLEMENTASI MODEL TGT UNTUK MENINGKATKAN AKTIVITAS BELAJAR DAN HASIL BELAJAR AKUNTANSI
}

\section{THE IMPLEMENTATION OF TGT METHOD TO IMPROVE ACCOUNTING LEARNING ACTIVITY AND LEARNING OUTCOME}

\author{
Oleh: \\ Nita Lestari \\ Prodi Pendidikan Akuntansi Universitas Negeri Yogyakarta \\ ni3tha94@gmail.com \\ $\underline{\text { Sukanti }}$ \\ Staf Pengajar Jurusan Pendidikan Akuntansi Universitas Negeri Yogyakarta
}

\begin{abstract}
Abstrak
Penelitian Tindakan Kelas ini bertujuan untuk meningkatkan Aktivitas Belajar dan Hasil Belajar Akuntansi Siswa Kelas XI Akuntansi 3 SMK Negeri 1 Godean Tahun Ajaran 2016/2017 melalui implementasi Model Pembelajaran Kooperatif Tipe Teams Games Tournament. Teknik pengumpulan data yang digunakan adalah observasi partisipatif, tes, dan dokumentasi. Teknik analisis data yang digunakan yaitu analisis data deskriptif kuantitatif. Berdasarkan hasil penelitian dapat disimpulkan bahwa implementasi Model Pembelajaran Kooperatif Tipe Teams Games Tournament dapat meningkatkan Aktivitas Belajar dan Hasil Belajar Akuntansi Siswa Kelas XI Akuntansi 3 SMK Negeri 1 Godean Tahun Ajaran 2016/2017. Skor rata-rata Aktivitas Belajar Akuntansi meningkat dari siklus I sebesar $67,30 \%$ menjadi $90,92 \%$ atau meningkat sebesar 23,62\%. Pada siklus I, rata-rata Hasil Belajar Akuntansi pada pre test sebesar 45,82 meningkat menjadi 85,00 pada post test atau meningkat sebesar 39,18. Pada siklus II, nilai rata-rata Hasil Belajar Akuntansi siswa pada pre test sebesar 42,54 meningkat menjadi 82,40 pada post test atau meningkat sebesar 39,86.
\end{abstract}

Kata Kunci: Aktivitas Belajar Akuntansi, Hasil Belajar Akuntansi, Model Pembelajaran Kooperatif Tipe Teams Games Tournament

\begin{abstract}
This study aimed to improve student's accounting learning activity and learning outcome of class XI Accounting 3 SMK Negeri 1 Godean Academic Year of 2016/2017 by implementing cooperative learning method type teams games tournament. The data collection techniques used participant observation, test and documentation. The data analysis technique in this research used quantitative descriptive data analysis. Based on the research result, it can be conclude that the implementation of cooperative learning method type teams games tournament was able to improve student's accounting learning activity and learning outcome of class XI accounting 3 SMK Negeri 1 Godean academic year of 2016/2017. The average score of accounting learning activity increase from the cycle I of $67,30 \%$ to $90,92 \%$ on the cycle to or increased of $23,62 \%$. On the cycle I, the average score of accounting learning outcome in pre test of 45,82 increased to 85,00 in the post test or increased of 39,18 . On the cycle II, the average score of accounting learning outcome in pre test of 42,54 increased to 82,40 in the post test or increased of 39,86.
\end{abstract}

Keyword: Accounting Learning Activity, Accounting Learning Outcome, Cooperative Learning Method Type Teams Games Tournament. 


\section{PENDAHULUAN}

Pendidikan memegang peranan penting dalam memajukan kehidupan suatu bangsa. Menurut P.H Coombs, pendidikan mencakup berbagai komponen yang saling mempengaruhi, di antaranya: tujuan dan prioritas, peserta didik, manajemen, struktur dan jadwal waktu, isi/ materi, guru dan pelaksana, alat dan sumber belajar, fasilitas, teknologi, pengawasan mutu, penelitian dan biaya pendidikan (Zainal Arifin, 2013: 3940). Kombinasi yang tepat dari berbagai komponen tersebut akan menentukan keberhasilan pendidikan. Dalam proses pendidikan, guru memegang peranan yang sangat penting. Selain sebagai perencana dan pelaksana pembelajaran, guru juga berperan dalam menilai proses dan hasil belajar peserta didik melalui kegiatan evaluasi. Secara umum, evaluasi dilakukan dengan tujuan untuk melihat sejauh mana kemajuan belajar para siswa telah tercapai dalam program pendidikan yang telah dilaksanakan (Oemar Hamalik, 2011: 211). Melalui kegiatan evaluasi inilah keberhasilan pendidikan diukur.

Pendidikan tidak hanya ditujukan untuk mencapai hasil belajar, tetapi juga melibatkan proses belajar yang terjadi dalam diri anak. Proses dan hasil belajar merupakan dua hal yang saling berkaitan, di mana hasil merupakan akibat dari proses (Nana Sudjana, 2013: 3). Dalam proses belajar mengajar sangat diperlukan adanya aktivitas. Tanpa aktivitas, proses belajar tidak mungkin berlangsung dengan baik (Sardiman A.M, 2011:97). Pembelajaran harus berorientasi kepada siswa dan menempatkan siswa sebagai subjek belajar. Dengan menjadikan siswa sebagai subjek belajar, diharapkan kegiatan belajar mengajar dapat berjalan efektif dan optimal. Efektifitas kegiatan belajar mengajar ini pada akhirnya akan berdampak pada meningkatnya Hasil Belajar Akuntansi.

Hasil Belajar Akuntansi merupakan kemampuan yang dimiliki siswa sebagai hasil dari proses belajar mengajar akuntansi dan mencakup bidang kognitif, afektif dan psikomotorik. Ketiga bidang tersebut merupakan objek penilaian hasil belajar. Hasil Belajar Akuntansi dipengaruhi oleh beberapa faktor, yaitu: faktor internal dan faktor eksternal. Faktor-faktor itulah yang mengakibatkan Hasil Belajar Akuntansi antara siswa satu dengan siswa yang lain mungkin berbeda.

Berdasarkan hasil observasi yang dilakukan oleh peneliti pada tanggal 2 September 2016 di kelas XI Akuntansi 3 SMK Negeri 1 Godean tahun ajaran 2016/2017, diketahui bahwa Aktivitas Belajar Akuntansi siswa masih rendah. Hal ini ditunjukkan dari 33 siswa, hanya 5 siswa $(15,15 \%)$ yang aktif bertanya dan menjawab pertanyaan serta 18 siswa $(54,55 \%)$ yang aktif mencatat. Selain itu, masih terdapat 10 siswa (30,30\%) yang justru melakukan aktivitas lain di luar konteks pembelajaran. Mereka tidak mendengarkan penjelasan guru dan justru berbicara dengan teman sebangkunya.

Berdasarkan hasil dokumentasi nilai ulangan harian pada Standar Kompetensi Menyajikan Laporan Harga Pokok Produk, juga diketahui bahwa Hasil Belajar Akuntansi siswa kelas XI Akuntansi 3 SMK Negeri 1 Godean tahun ajaran 2016/2017 masih rendah. Hal ini ditunjukkan dari 33 siswa, sebanyak 20 siswa $(60,61 \%)$ belum mencapai KKM. Adapun besarnya Kriteria Ketuntasan Minimal (KKM) yang telah ditentukan adalah sebesar 78. Selain itu, berdasarkan hasil wawancara diketahui bahwa rendahnya Aktivitas Belajar dan Hasil Belajar Akuntansi ini dipengaruhi oleh metode pembelajaran yang digunakan oleh guru masih konvensional, yakni menggunakan metode ceramah. Hal ini menyebabkan siswa kurang aktif dan kurang termotivasi untuk mempelajari materi yang disampaikan oleh guru. Oleh sebab itu, diperlukan pemilihan metode pembelajaran yang tepat agar kegiatan pembelajaran dapat berjalan dengan efektif.

Menurut Syaiful Bahri Djamarah (2010: 229-233), ada beberapa faktor yang harus dipertimbangkan dalam pemilihan 
metode mengajar, yaitu: kesesuaian dengan tujuan, perbedaan individual peserta didik, kemampuan guru, sifat bahan pelajaran, situasi kelas, fasilitas yang tersedia, serta kelebihan dan kelemahan metode. Salah satu model pembelajaran yang dapat digunakan guru adalah model pembelajaran kooperatif. Penggunaan model pembelajaran kooperatif sangat dianjurkan oleh para ahli. Hal ini dikarenakan, model pembelajaran kooperatif memiliki beberapa keunggulan, yaitu mengurangi ketergantungan siswa terhadap guru, memberdayakan siswa untuk lebih bertanggung jawab dalam belajar, meningkatkan prestasi akademik, dan meningkatkan aktivitas belajar siswa (Wina Sanjaya, 2013: 249-250).

\section{METODE PENELITIAN Desain Penelitian}

Penelitian ini merupakan Penelitian Tindakan Kelas. Menurut Pardjono (2007: 12), Penelitian Tindakan Kelas merupakan salah satu jenis penelitian tindakan yang dilakukan guru untuk meningkatkan kualitas pembelajaran di kelasnya. Penelitian Tindakan Kelas ini menggunakan empat komponen penelitian dalam setiap langkah, yaitu perencanaan, tindakan, observasi dan refleksi.

\section{Tempat dan Waktu Penelitian}

Penelitian ini dilaksanakan di kelas XI Akuntansi 3 SMK Negeri 1 Godean yang beralamat di Kowanan, Sidoagung, Godean, Sleman, Yogyakarta. Penelitian ini dilaksanakan dalam beberapa tahap, yaitu tahap persiapan, pelaksanaan, dan pelaporan. Tahap persiapan dimulai pada bulan Oktober 2016, sedangkan tahap pelaksanaan dan pelaporan dilakukan pada bulan November 2016 sampai dengan bulan Januari 2017.

\section{Subjek dan Objek Penelitian}

Subjek dalam penelitian ini adalah siswa kelas XI Akuntansi 3 SMK Negeri 1 Godean tahun ajaran 2016/2017 yang terdiri dari 33 siswa. Objek dalam penelitian ini adalah Aktivitas Belajar dan Hasil Belajar Akuntansi siswa kelas XI Akuntansi 3 SMK Negeri 1 Godean.

\section{Prosedur Penelitian}

Penelitian ini merupakan Penelitian Tindakan Kelas yang dilakukan dalam empat tahap yaitu perencanaan, pelaksanaan, observasi dan refleksi. Keempat tahap tersebut membentuk sebuah siklus. Penelitian ini telah dilaksanakan dalam dua siklus. Berikut ini adalah prosedur penelitian yang dilakukan:

a. Siklus I

1) Perencanaan

Pada tahap ini peneliti menyiapkan berbagai hal yang akan digunakan dalam penelitian yaitu menyusun Rencana Pelaksanaan Pembelajaran (RPP) dengan menggunakan Model Pembelajaran Kooperatif Tipe Teams Games Tournament pada materi pokok Pemakaian Biaya Tenaga Kerja, membuat jadwal pelaksanaan kegiatan pembelajaran, menyiapkan materi tentang Pemakaian Biaya Tenaga Kerja, menyiapkan soal pre test dan post test, menyiapkan soal turnamen dan soal cadangan, membuat pedoman observasi, menyiapkan format catatan lapangan, membagi siswa ke dalam 8 kelompok secara heterogen, Menyiapkan name tag yang berisi nomor presensi siswa, nomor meja dan kartu rekap skor, menyiapkan power point, 4 buah papan, 4 spidol dan kertas HVS, dan mengkonsultasikan kepada guru yang bersangkutan mengenai semua persiapan yang telah dilakukan.

2) Pelaksanaan

Tahap pelaksanaan merupakan tahap untuk mengimplementasikan perencanaan yaitu guru melaksanakan proses pembelajaran dengan mengimplementasikan Model Pembelajaran Kooperatif Tipe Teams Games Tournament. 
Tahap pelaksanaan yang dilakukan di kelas disesuaikan dengan RPP yang dibuat yang meliputi kegiatan pendahuluan, kegiatan inti (tahap mengajar, belajar tim, games, dan tournament) dan kegiatan penutup. Pada tahap ini juga dilakukan pengamatan selama proses pembelajaran berlangsung. Fokus pengamatan dilakukan untuk mengamati Aktivitas Belajar dan Hasil Belajar Akuntansi.

3) Refleksi

Dalam tahap ini, dilakukan evaluasi mengenai pelaksanaan tindakan yang telah dilaksanakan berdasarkan hasil pre test, post test, lembar observasi dan catatan lapangan. Refleksi dilakukan dengan tujuan untuk mengetahui kelebihan dan kekurangan pelaksanaan kegiatan pembelajaran. Hasil refleksi ini digunakan untuk memperbaiki kegiatan pada siklus II jika pada siklus I belum menunjukkan hasil yang optimal.

b. Siklus II

1) Perencanaan

Tahap perencanaan pada siklus II secara garis besar hampir sama dengan siklus I. Hanya saja, pada siklus II ini terdapat beberapa upaya perbaikan yang diperlukan berdasarkan hasil penelitian pada siklus I. Materi pokok pada siklus II yaitu Pemakaian Biaya Overhead Pabrik.

2) Pelaksanaan

Tahap pelaksanaan pada siklus II sama dengan siklus I. Proses pembelajaran disesuaikan dengan RPP yang telah dibuat. Materi yang disampaikan dalam siklus II yaitu Pemakaian Biaya Overhead Pabrik. Pada tahap ini juga dilakukan pengamatan terhadap Aktivitas Belajar dan Hasil Belajar Akuntansi.

3) Refleksi
Tahap refleksi pada siklus II dilakukan untuk mengetahui peningkatan Aktivitas Belajar dan Hasil Belajar Akuntansi dari kegiatan pembelajaran yang dilakukan pada siklus I dan siklus II. Hal ini berguna untuk menentukan langkah selanjutnya, yaitu apakah akan menambah siklus atau tidak. Jika peningkatan yang diharapkan telah tercapai, maka tidak perlu dilakukan penambahan siklus.

\section{Teknik Pengumpulan Data}

Teknik pengumpulan data yang digunakan dalam penelitian ini yaitu observasi partisipatif, tes, dan dokumentasi. Observasi partisipatif dilakukan untuk mengamati Aktivitas Belajar Akuntansi, sedangkan tes digunakan untuk mengukur Hasil Belajar Akuntansi ranah kognitif (pengetahuan, pemahaman, dan penerapan) tentang materi Pemakaian Biaya Tenaga Kerja dan Pemakaian Biaya Overhead Pabrik. Selain itu, dokumentasi juga diperlukan untuk memperoleh data jumlah siswa dan data Hasil Belajar Akuntansi sebagai data awal penelitian.

\section{Instrumen Penelitian}

Instrumen penelitian yang digunakan dalam penelitian ini yaitu lembar observasi, tes, dan catatan lapangan. Lembar observasi ini disusun dengan menggunakan rating scale di mana di dalamnya memuat indikator Aktivitas Belajar Akuntansi yang diamati dan pedoman penskorannya. Tes yang digunakan dalam penelitian ini berbentuk soal uraian dan objektif yang pembuatannya dikonsultasikan terlebih dahulu dengan guru yang bersangkutan. Tes yang diberikan berupa soal pre test dan post test untuk mengukur peningkatan Hasil Belajar Akuntansi. Catatan lapangan digunakan untuk mencatat berita acara pelaksanaan pembelajaran berupa catatan kejadian seperti interaksi siswa dengan guru, siswa dengan siswa, dan lain sebagainya. Catatan lapangan dibuat untuk setiap siklusnya. 


\section{Teknik Analisis Data}

a. Analisis Deskriptif Kuantitatif

1) Analisis kualitas tes

Analisis kualitas tes ini dapat dilihat dari validitas, reliabilitas, tingkat kesukaran, daya pembeda, dan pola jawaban soal. Analisis dilakukan dengan menggunakan sofware Anates V4.

2) Menghitung skor Aktivitas Belajar Akuntansi

Perhitungan persentase rata-rata Aktivitas Belajar Akuntansi siswa dengan menggunakan rumus: jumlah skoy seluruh indikator aktivitas belajay $\mathrm{X}$ jumiah shor maksimum seluruh indikator $100 \%$

3) Menghitung Peningkatan Hasil Belajar Akuntansi

Peningkatan Hasil Belajar Akuntansi dapat diketahui dengan menggunakan rumus berikut:

$M e=\frac{\text { lumlah semua milai }}{\text { Jumlah siswa }}$

Selain itu, ketuntasan Hasil Belajar Akuntansi dapat dihitung dengan menggunakan rumus berikut:

$$
\begin{aligned}
\mathrm{KB}= & \frac{\text { Jumlah siswa yang memenuhi } K K M}{\text { Jumlah siswa yang mengikuti tes }} \mathrm{X} \\
& 100 \%
\end{aligned}
$$

b. Penyajian data

Data yang telah diolah kemudian akan disajikan ke dalam bentuk tabel dan grafik. Dari tabel dan grafik tersebut kemudian akan dinarasikan agar lebih mudah dipahami.

c. Penarikan kesimpulan

Penarikan kesimpulan merupakan tahap akhir dalam analisis data. Setelah data disajikan, data akan diambil intisari untuk kemudian dituliskan dalam bentuk pernyataan yang memiliki makna lebih tegas atas hasil analisis yang telah dilakukan.

\section{Indikator Keberhasilan}

Indikator keberhasilan Aktivitas Belajar Akuntansi dalam penelitian ini yaitu apabila terjadi peningkatan skor rata-rata Aktivitas Belajar Akuntansi dari siklus I ke siklus II. Selain itu, indikator keberhasilan Aktivitas Belajar Akuntansi juga dapat dicapai apabila terdapat minimal $75 \%$ dari jumlah siswa dalam satu kelas yang aktif dalam kegiatan pembelajaran.

Indikator keberhasilan Hasil Belajar Akuntansi dalam penelitian ini yaitu apabila terjadi peningkatan skor rata-rata Hasil Belajar Akuntansi pada siklus I dan siklus II. Selain itu, indikator keberhasilan dalam penelitian ini juga dapat dicapai apabila terdapat minimal $75 \%$ dari jumlah siswa dalam satu kelas yang mencapai Kriteria Ketuntasan Minimal (KKM) yang telah ditentukan oleh pihak sekolah, yaitu sebesar 78 .

\section{HASIL PENELITIAN DAN PEMBAHASAN}

Penelitian yang telah dilakukan membuktikan bahwa implementasi Model Pembelajaran Kooperatif Tipe Teams Games Tournament dapat meningkatkan Aktivitas Belajar dan Hasil Belajar Akuntansi siswa kelas XI Akuntansi 3 SMK Negeri 1 Godean tahun ajaran 2016/2017. Penelitian ini dilaksanakan melalui dua siklus di mana siklus I dilaksanakan pada tanggal 16 November 2016, sedangkan siklus II dilaksanakan pada tanggal 18 November 2016. Proses pembelajaran dengan implementasi Model Pembelajaran Kooperatif Tipe Teams Games Tournament pada siklus I dan siklus II menunjukkan adanya peningkatan Aktivitas Belajar Akuntansi. Peningkatan skor rata-rata Aktivitas Belajar Akuntansi pada siklus I dan siklus II dapat dilihat pada tabel di bawah ini: 
Tabel 1. Peningkatan Skor Aktivitas Belajar Akuntansi pada Siklus I dan Siklus II

\begin{tabular}{|c|c|c|c|c|c|}
\hline \multirow[t]{2}{*}{$\begin{array}{l}\mathbf{N} \\
\mathbf{0}\end{array}$} & \multirow[t]{2}{*}{ Indikator } & \multicolumn{2}{|c|}{$\begin{array}{c}\text { Skor } \\
\text { Aktivitas } \\
\text { Belajar } \\
\text { Akuntansi } \\
\text { Siklus... } \\
\end{array}$} & \multicolumn{2}{|c|}{$\begin{array}{l}\text { Peningka } \\
\tan (\mathrm{I}-\mathrm{II})\end{array}$} \\
\hline & & $\begin{array}{c}\text { I } \\
(\% \\
\end{array}$ & $\underset{(\%)}{\text { II }}$ & $\begin{array}{l}\text { Abs } \\
\text { olut } \\
(\%)\end{array}$ & $\begin{array}{c}\text { Rela } \\
\text { tif } \\
(\%)\end{array}$ \\
\hline 1 & $\begin{array}{l}\text { Membaca } \\
\text { materi } \\
\text { pelajaran }\end{array}$ & $\begin{array}{r}71 \\
72\end{array}$ & $\begin{array}{r}95,2 \\
4\end{array}$ & $\begin{array}{r}23,5 \\
2\end{array}$ & $\begin{array}{c}32,7 \\
9\end{array}$ \\
\hline 2 & $\begin{array}{l}\text { Memperha } \\
\text { tikan } \\
\text { penjelasan } \\
\text { terkait } \\
\text { materi } \\
\text { pelajaran } \\
\text { yang } \\
\text { disampaik } \\
\text { an. }\end{array}$ & $\begin{array}{r}75 \\
76\end{array}$ & $\begin{array}{r}89,2 \\
9\end{array}$ & $\begin{array}{r}13,5 \\
3\end{array}$ & $\begin{array}{c}17,8 \\
6\end{array}$ \\
\hline 3 & $\begin{array}{l}\text { Mengajuk } \\
\text { an } \\
\text { pertanyaan } \\
\text { terkait } \\
\text { materi } \\
\text { pelajaran } \\
\text { yang } \\
\text { disampaik } \\
\text { an. }\end{array}$ & $\begin{array}{r}33 \\
33\end{array}$ & $\begin{array}{r}82,1 \\
4\end{array}$ & $\begin{array}{r}48,8 \\
1\end{array}$ & $\begin{array}{c}146 \\
44\end{array}$ \\
\hline 4 & $\begin{array}{l}\text { Memberik } \\
\text { an } \\
\text { pendapat } \\
\text { dan } \\
\text { jawaban } \\
\text { terkait } \\
\text { materi } \\
\text { pelajaran } \\
\text { yang } \\
\text { disampaik } \\
\text { an. } \\
\end{array}$ & $\begin{array}{r}47 \\
47\end{array}$ & $\begin{array}{r}79,7 \\
6\end{array}$ & $\begin{array}{r}32,2 \\
9\end{array}$ & $\begin{array}{c}68,0 \\
2\end{array}$ \\
\hline 5 & $\begin{array}{l}\text { Melakuka } \\
\text { n diskusi } \\
\text { kelompok }\end{array}$ & $\begin{array}{r}78 \\
79\end{array}$ & $\begin{array}{r}97,6 \\
2\end{array}$ & $\begin{array}{r}18,8 \\
3\end{array}$ & $\begin{array}{r}23,9 \\
0\end{array}$ \\
\hline 6 & $\begin{array}{l}\text { Mendenga } \\
\text { rkan }\end{array}$ & $\begin{array}{r}77 \\
78\end{array}$ & $\begin{array}{r}95,2 \\
4 \\
\end{array}$ & $\begin{array}{r}17,4 \\
6 \\
\end{array}$ & $\begin{array}{r}22,4 \\
5 \\
\end{array}$ \\
\hline
\end{tabular}

\begin{tabular}{|c|c|c|c|c|c|}
\hline \multirow[t]{2}{*}{$\begin{array}{l}\mathbf{N} \\
\mathbf{0}\end{array}$} & \multirow[t]{2}{*}{ Indikator } & \multicolumn{2}{|c|}{$\begin{array}{c}\text { Skor } \\
\text { Aktivitas } \\
\text { Belajar } \\
\text { Akuntansi } \\
\text { Siklus... }\end{array}$} & \multicolumn{2}{|c|}{$\begin{array}{l}\text { Peningka } \\
\tan (\mathrm{I}-\mathrm{II})\end{array}$} \\
\hline & & $\begin{array}{c}I \\
(\% \\
)\end{array}$ & $\underset{(\%)}{\text { II }}$ & $\begin{array}{l}\text { Abs } \\
\text { olut } \\
(\%)\end{array}$ & $\begin{array}{c}\text { Rela } \\
\text { tif } \\
(\%)\end{array}$ \\
\hline & \begin{tabular}{|l} 
penjelasan \\
terkait \\
materi \\
pelajaran \\
yang \\
disampaik \\
an. \\
\end{tabular} & & & & \\
\hline 7 & \begin{tabular}{|l} 
Mencatat \\
materi \\
pelajaran
\end{tabular} & $\begin{array}{r}58 \\
59\end{array}$ & $\begin{array}{r}88,1 \\
0\end{array}$ & $\begin{array}{r}29,5 \\
1\end{array}$ & $\begin{array}{r}50,3 \\
7\end{array}$ \\
\hline 8 & $\begin{array}{l}\text { Mengerjak } \\
\text { an soal pre } \\
\text { test dan } \\
\text { post test } \\
\text { yang } \\
\text { diberikan. }\end{array}$ & $\begin{array}{r}94, \\
95\end{array}$ & $\begin{array}{r}100, \\
00\end{array}$ & 5,05 & 5,32 \\
\hline & $\begin{array}{l}\text { kor Rata- } \\
\text { Rata } \\
\text { Aktivitas } \\
\text { Belajar } \\
\text { kuntansi }\end{array}$ & $\begin{array}{r}67, \\
30\end{array}$ & $\begin{array}{r}90,9 \\
2\end{array}$ & $\begin{array}{r}23,6 \\
2\end{array}$ & \\
\hline
\end{tabular}

Sumber: Data Primer yang Diolah

Berdasarkan tabel di atas dapat disimpulkan rata-rata Aktivitas Belajar Akuntansi meningkat dari siklus I yaitu sebesar $67,30 \%$ menjadi $90,92 \%$ pada siklus II, dimana terjadi peningkatan absolut sebesar 23,62\% dan peningkatan relatif sebesar $35,10 \%$. Peningkatan Aktivitas Belajar Akuntansi ini juga bisa dilihat secara individual, yaitu dengan menentukan jumlah siswa yang telah mencapai indikator Aktivitas Belajar Akuntansi atau siswa yang mempunyai skor Aktivitas Belajar Akuntansi $\geq 75 \%$ pada siklus I dan siklus II. Peningkatan terrsebut dapat dilihat pada tabel di bawah ini: 
Tabel 2. Peningkatan Skor Aktivitas Belajar Akuntansi pada Siklus I danSiklus II

\begin{tabular}{|c|c|c|c|c|c|}
\hline \multirow{2}{*}{$\begin{array}{c}\text { Kat } \\
\text { ego } \\
\text { ri }\end{array}$} & $\begin{array}{c}|c| \\
\text { Sr } \\
\text { ek } \\
\text { ue } \\
\text { nsi }\end{array}$ & $\%$ & $\begin{array}{c}\text { Fr } \\
\text { ek } \\
\text { ue } \\
\text { nsi }\end{array}$ & $\%$ & $\begin{array}{c}\text { Penin } \\
\text { gkata } \\
\text { n (I- } \\
\text { II) }\end{array}$ \\
\hline $\begin{array}{l}\mathrm{N} \geq \\
75 \\
\%\end{array}$ & 7 & $\begin{array}{c}21,2 \\
1\end{array}$ & 28 & $\begin{array}{c}\text { Siklus II } \\
00\end{array}$ & 78,79 \\
\hline
\end{tabular}

Sumber: Data Primer yang Diolah Keterangan: $\mathrm{N}=$ Persentase Skor RataRata Aktivitas Belajar Akuntansi

Berdasarkan tabel di atas, dapat diketahui bahwa secara individual, jumlah siswa yang memperoleh skor Aktivitas Belajar Akuntansi $\geq 75 \%$ pada siklus I sebanyak 7 siswa $(21,21 \%)$ meningkat menjadi 28 orang (100\%) pada siklus II. Hal ini menunjukkan bahwa ada peningkatan sebanyak 21 siswa (78,79\%). Peningkatan Aktivitas Belajar Akuntansi ini telah mencapai indikator Aktivitas Belajar Akuntansi yang telah ditentukan. Oleh sebab itu, hipotesis tindakan dinyatakan sudah terjawab.

Proses pembelajaran dengan implementasi Model Pembelajaran Kooperatif Tipe Teams Games Tournament pada siklus I dan siklus II juga menunjukkan adanya peningkatan Hasil Belajar Akuntansi, khususnya ranah kognitif. Peningkatan nilai rata-rata Hasil Belajar Akuntansi pada siklus I dan siklus II dapat dilihat pada tabel di bawah ini:

Tabel 3. Peningkatan Nilai Rata-Rata Hasil Belajar Akuntansi pada Siklus I dan Siklus II

\begin{tabular}{|c|c|c|c|c|}
\hline Si & \multicolumn{2}{|c|}{$\begin{array}{c}\text { Nilai Rata-Rata } \\
\text { kl }\end{array}$} & \multicolumn{2}{|c|}{ Peningkatan } \\
\cline { 2 - 5 } uelas & Pre & $\begin{array}{c}\text { Post } \\
\text { S }\end{array}$ & $\begin{array}{c}\text { Absol } \\
\text { Test }\end{array}$ & $\begin{array}{c}\text { Rest } \\
\text { Test }\end{array}$ \\
\hline I & 45,82 & 85,00 & 39,18 & 85,51 \\
\hline II & 42,54 & 82,40 & 39,86 & 93,70 \\
\hline
\end{tabular}

Sumber: Data Primer yang Diolah
Berdasarkan tabel di atas, diketahui bahwa telah terjadi peningkatan rata-rata Hasil Belajar Akuntansi pada siklus I dan siklus II setelah adanya implementasi Model Pembelajaran Kooperatif Tipe Teams Games Tournament. Rata-rata Hasil Belajar Akuntansi pada pre test siklus I sebesar 45,82 meningkat menjadi sebesar 85,00 pada post test atau meningkat sebesar 39,18 atau $85,51 \%$. Pada siklus II, nilai rata-rata Hasil Belajar Akuntansi pada pre test sebesar 42,54 meningkat menjadi sebesar 82,40 pada post test atau meningkat sebesar 39,86 atau $93,70 \%$.

Peningkatan Hasil Belajar Akuntansi juga dapat dilihat dari peningkatan ketuntasan Hasil Belajar Akuntansi pada siklus I dan siklus II. Berikut ini adalah tabel ketuntasan Hasil Belajar Akuntansi pada siklus I dan siklus II:

Tabel 4. Peningkatan Ketuntasan Hasil Belajar Akuntansi pada Siklus I dan Siklus II

\begin{tabular}{|c|c|c|c|c|c|}
\hline \multirow{3}{*}{$\begin{array}{l}\text { Si } \\
\text { kl } \\
\text { us }\end{array}$} & \multicolumn{4}{|c|}{$\begin{array}{c}\text { Ketuntasan Hasil Belajar } \\
\text { Akuntansi }\end{array}$} & \multirow{3}{*}{$\begin{array}{c}\text { Peni } \\
\text { ngka } \\
\text { tan } \\
(\%)\end{array}$} \\
\hline & \multicolumn{2}{|c|}{ Pre Test } & \multicolumn{2}{|c|}{ Post Test } & \\
\hline & $\begin{array}{l}N \\
\geq \\
78\end{array}$ & $\%$ & $\begin{array}{c}N \geq \\
78\end{array}$ & $\%$ & \\
\hline I & 4 & 12,12 & 24 & 72,73 & $\begin{array}{r}60,6 \\
1\end{array}$ \\
\hline II & 0 & 0,00 & 22 & 78,57 & $\begin{array}{r}78,5 \\
7\end{array}$ \\
\hline
\end{tabular}

Sumber: Data Primer yang Diolah

Keterangan: $\mathrm{N}=$ Nilai

Berdasarkan tabel di atas diketahui bahwa telah terjadi peningkatan Hasil Belajar Akuntansi setelah adanya implementasi Model Pembelajaran Kooperatif Tipe Teams Games Tournament. Ketuntasan Hasil Belajar Akuntansi pada pre test siklus I sebesar $12,12 \%$ meningkat menjadi $72,73 \%$ pada post test atau meningkat sebesar 60,61\%. Pada siklus II, ketuntasan Hasil Belajar Akuntansi pada pre test $0,00 \%$ meningkat menjadi $78,57 \%$ pada post test atau meningkat sebesar $78,57 \%$. Dengan 
demikian dapat disimpulkan bahwa peningkatan Hasil Belajar Akuntansi telah mencapai indikator keberhasilan yang telah ditentukan sehingga hipotesis tindakan dinyatakan sudah terjawab.

\section{SIMPULAN DAN SARAN \\ Simpulan}

Berdasarkan hasil penelitian dan pembahasan, maka dapat disimpulkan bahwa:

a. Implementasi Model Pembelajaran Kooperatif Tipe Teams Games Tournament dapat meningkatkan Aktivitas Belajar Akuntansi siswa kelas XI akuntansi 3 SMK Negeri 1 Godean tahun ajaran 2016/2017. Hal ini dibuktikan dengan peningkatan skor ratarata Aktivitas Belajar Akuntansi dan peningkatan jumlah siswa yang memperoleh skor Aktivitas Belajar Akuntansi $\geq 75 \%$ dari siklus I ke siklus II. Skor rata-rata Aktivitas Belajar Akuntansi meningkat dari siklus I sebesar $67,30 \%$ menjadi $90,92 \%$ pada siklus II, atau meningkat sebesar $23,62 \%$ atau $35,10 \%$. Jumlah siswa yang memperoleh skor Aktivitas Belajar Akuntansi $\geq 75 \%$ meningkat dari siklus I sebanyak 7 siswa $(21,21 \%)$ menjadi 28 siswa $(100 \%)$ pada siklus II atau meningkat sebesar 78,79\%.

b. Implementasi Model Pembelajaran Kooperatif Tipe Teams Games Tournament dapat meningkatkan Hasil Belajar Akuntansi siswa kelas XI akuntansi 3 SMK Negeri 1 Godean tahun ajaran 2016/2017. Hal ini dibuktikan dengan peningkatan nilai rata-rata Hasil Belajar Akuntansi dan peningkatan ketuntasan Hasil Belajar Akuntansi dari siklus I ke siklus II. Rata-rata Hasil Belajar Akuntansi pada pre test siklus I sebesar 45,82 meningkat menjadi sebesar 85,00 pada post test atau meningkat sebesar 39,18 atau 85,51\%. Pada siklus II, rata-rata Hasil Belajar Akuntansi pada pre test sebesar 42,54 meningkat menjadi sebesar 82,40 pada post test atau meningkat sebesar 39,86 atau $93,70 \%$.
Ketuntasan Hasil Belajar Akuntansi pada pre test siklus I sebesar 12,12\% meningkat menjadi $72,73 \%$ pada post test atau meningkat sebesar 60,61\%. Pada siklus II, ketuntasan Hasil Belajar Akuntansi pada pre test 0,00\% meningkat menjadi $78,57 \%$ pada post test atau meningkat sebesar $78,57 \%$.

\section{Saran}

a. Bagi Guru

1) Model Pembelajaran Kooperatif Tipe Teams Games Tournament sebaiknya lebih sering digunakan karena terbukti dapat meningkatkan Aktivitas Belajar dan Hasil Belajar Akuntansi. Bahkan, bila perlu diuji cobakan pada materi pokok lain.

2) Model Pembelajaran Kooperatif Tipe Teams Games Tournament sebaiknya tidak diimplementasikan dalam waktu singkat agar proses pembelajaran lebih optimal. Hal ini ditujukan agar guru memiliki cukup waktu untuk penyampaian materi dan siswa memiliki cukup waktu untuk kegiatan diskusi dan tanya jawab.

b. Bagi Peneliti Lain

Peneliti lain sebaiknya juga meneliti respon siswa terhadap implementasi Model Pembelajaran Kooperatif Tipe Teams Games Tournament. Hasil angket respon siswa selanjutnya dapat digunakan untuk perbaikan dan penyempurnaan dalam penerapannya.

\section{DAFTAR PUSTAKA}

Nana Sudjana. (2013). Penilaian Hasil Proses Belajar Mengajar. Bandung: PT Remaja Rosdakarya.

Oemar Hamalik (2011). Perencanaan Pengajaran Berdasarkan Pendekatan Sistem. Jakarta: Bumi Aksara.

Pardjono, dkk. (2007). Panduan Penelitian Tindakan Kelas. Yogyakarta: Lembaga Penelitian UNY. 
$1-9$

Sardiman A.M. (2011). Interaksi dan Motivasi Belajar Mengajar. Jakarta: Rajawali Press.

Syaiful Bahri Djamarah. (2010). Guru dan Anak Didik dalam Interaksi Edukatif: Suatu Pendekatan Teoritis Psikologis. Jakarta: Rineka Cipta.

Wina Sanjaya. (2013). Strategi Pembelajaran Berorientasi Standar Proses Pendidikan. Jakarta: Kencana Prenadamedia Group.

Zainal Arifin. (2013). Evaluasi Pembelajaran. Bandung: PT Remaja Rosdakarya. 